\title{
Dehydroepiandrosterone (DHEA) modulates GHRH, somatostatin and angiotensin II action at the pituitary level
}

\author{
C Suárez, J Vela, I García-Tornadú and D Becu-Villalobos \\ Instituto de Biología y Medicina Experimental, CONICET, V, Obligado 2490, Buenos Aires 1428, Argentina \\ (Requests for offprints should be addressed to D Becu-Villalobos; Email: dbecu@dna.uba.ar)
}

\begin{abstract}
In view of the present controversy related to the potential beneficial effects of clinical dehydroepiandrosterone (DHEA) treatments, and considering our own previous results that reveal an influence of this steroid in pituitary hyperplasia development in vivo in rats, we decided to evaluate the role of DHEA in prolactin and GH secretion, as well as in second messengers involved, in cultured rat anterior pituitary cells. DHEA $\left(1 \times 10^{-5}\right.$ to $\left.1 \times 10^{-7} \mathrm{M}\right)$ did not modify basal $\mathrm{GH}$ or prolactin release, and a prolactin inhibitory effect was observed only for androstenediol, a metabolite of DHEA. DHEA partially prevented dopamine $\left(1 \times 10^{-6} \mathrm{M}\right)$-induced prolactin inhibition and facilitated the prolactin-releasing effect of $10^{-8} \mathrm{M}$ Ang II, without modifying the resulting $\mathrm{Ca}^{2+}{ }_{\mathrm{i}}$
\end{abstract}

mobilization. Furthermore, DHEA potentiated the GH release and cAMP production induced by $1 \times 10^{-8} \mathrm{M}$ GHRH. Finally, DHEA partially reversed the inhibitory effect of $1 \times 10^{-8} \mathrm{M}$ somatostatin on $\mathrm{GH}$, but not prolactin, release. We conclude that DHEA in vitro, directly or indirectly through conversion into metabolites, is able to modulate the hormonal response of the pituitary to hypothalamic regulators. It can enhance pituitary prolactin release and induce GH secretion. These effects could help explain some of the side effects observed in prolonged DHEA treatments in vivo and should be taken into account when considering its use in human clinical trials.

Journal of Endocrinology (2005) 185, 165-172

\section{Introduction}

Dehydroepiandrosterone (DHEA), unconjugated or as its sulphate, is the major secretory steroidal product of the human adrenal gland. Its serum concentration is 20 times higher than that of any other steroid hormone in humans (Ebeling \& Koivisto 1994). But, despite its abundance, its physiologic role is not yet completely known. In vitro and in vivo data suggest estrogen- or androgen-like effects of DHEA and its metabolites, depending on sex hormone homeostasis (Poortman et al. 1975). In particular the relation of DHEA to pituitary function has not been clearly defined.

Serum DHEA levels present a characteristic ontogenic pattern, with increasing values toward puberty and a progressive decline during aging, paralleling growth hormone $(\mathrm{GH})$ and insulin-like growth factor-I (IGF-I) values. In an aging society, this inevitably raises the question of whether aging is, in part, a consequence of DHEA deficiency and potentially reversible by DHEA treatment. Furthermore, a significant deficiency in DHEA in patients with several major diseases such as various cancers, inflammatory diseases, type II diabetes, atherosclerosis, Alzheimer's disease and cardiovascular disorders has been described (Shealy 1995, Allolio \& Arlt 2002).
These data suggest that DHEA could be a multifunctional hormone with anticancer, immune-enhancing, neurotropic and general antiaging effects. This idea has been strengthened by numerous animal experiments. However, most animal studies used pharmacologic DHEA doses, yielding serum DHEA levels far beyond the physiologic ones. Recently, a growing number of well-designed clinical trials has begun to shed light on the role of DHEA in human health.

DHEA, synthesized from pregnenolone by the cytochrome P450-C17, can be converted to androgens or estrogens. In rats, DHEA is metabolized in situ in many tissues mainly to $7 \alpha$-hydroxy DHEA (OH-DHEA) by the $\alpha$-hydroxylase CYP7B, or to 5 - $\alpha$-androstene- $3 \beta, 17 \beta$ diol (ADIOL), which can also be $\alpha$-hydroxylated, presumably by the same enzyme (Rose et al. 2001). The rat has proved to be an useful model to study the mechanism of action of DHEA. In a previous work we showed that this steroid attenuates estrogen-induced pituitary hyperplasia and hyperprolactinemia (Suárez et al. 2002). Besides, DHEA per se produced diverse hormonal effects, such as serum prolactin and GH increase in vivo, which would restrict the clinical application of this drug in humans. In the present study we wished to determine whether the in vivo hormonal effects described for DHEA could be 
accounted for by an action of DHEA or its metabolites, ADIOL and OH-DHEA, directly at the pituitary level. We therefore evaluated the effect of DHEA, OH-DHEA and ADIOL on prolactin and GH secretion in pituitary cells dispersed in vitro, in combination with wellestablished secretagogues such as angiotensin II (Ang II), dopamine, growth hormone-releasing hormone $(\mathrm{GHRH})$ and somatostatin. Furthermore, we investigated whether DHEA had any effect on GHRH and Ang II regulation of second messengers $\left(\left[\mathrm{Ca}^{2+}\right]_{\mathrm{i}}\right.$ and cAMP) that could participate in the actions described for the adrenal steroid at the pituitary level.

\section{Materials and Methods}

Animals

Female 60-day-old Sprague-Dawley rats were housed in an air-conditioned room with lights on at $0700 \mathrm{~h}$ and off at 1900 h. Rats were maintained in accordance with NIH Guide for the Care and Use of Laboratory Animals. Vaginal smears were performed daily and rats in diestrus were used.

\section{Drugs}

Unless specified, all chemicals were purchased from Sigma.

\section{Cell dispersion and culture}

Anterior pituitaries were placed in chambers containing freshly prepared Krebs-Ringer bicarbonate buffer without $\mathrm{Ca}^{2+}$ or $\mathrm{Mg}^{2+}$. Buffer containing $14 \mathrm{mM}$ glucose, $1 \%$ bovine serum albumin (BSA), 2\% MEM amino acids, 1\% MEM vitamins (Life Technologies, Buenos Aires, Argentina) and $2 \mathrm{mM}$ glutamine was previously gassed for 15 min with $95 \% \mathrm{O}_{2}$ and $5 \% \mathrm{CO}_{2}$ and adjusted to $\mathrm{pH}$ $7 \cdot 35-7 \cdot 40$. Buffer was sterilized by filtration through a $0 \cdot 45-\mu \mathrm{m}$ pore diameter membrane (Nalge Nunc International, Rochester, NY, USA). Pituitaries were washed three times with Krebs-Ringer bicarbonate buffer and then cut into $1 \mathrm{~mm}$ pieces. Fragments obtained were washed and incubated in the same buffer containing $0.5 \%$ trypsin for $30 \mathrm{~min}$ at $37{ }^{\circ} \mathrm{C}$ in $95 \% \mathrm{O}_{2}$ and $5 \% \mathrm{CO}_{2}$. They were treated for another $2 \mathrm{~min}$ with $50 \mu \mathrm{l}$ deoxyribonuclease I $(1 \mathrm{mg} / \mathrm{ml}$; Worthington Biochemical Corp., Lakewood, NJ, USA). Digestion was ended by adding $1 \mathrm{mg} / \mathrm{ml}$ lima bean trypsin inhibitor. Fragments were dissociated to single cells by gentle trituration through siliconized Pasteur pipettes. The resulting suspension was filtered through a nylon gauze $(160 \mu \mathrm{m}$ pore size $)$ and centrifuged for $10 \mathrm{~min}$ at $120 \mathrm{~g}$, and a cellular pellet was obtained. Before centrifugation, an aliquot of the cellular suspension was taken to quantify pituitary cell yield, using a Neubauer chamber. Viability of cells, as determined by
Trypan blue exclusion, was always greater than 90\%. Cells were freshly used for intracellular $\mathrm{Ca}^{2+}$ measurements (see below), or plated in sterile cell culture plates. Cells (50 000 cells/well) were cultured for 3 days. Cell culture was performed as previously described with minor modifications (Gonzalez Iglesias et al. 2000). DHEA, OH-DHEA, ADIOL, Human GHRH-(1-29)-amide (provided by the National Institute of Diabetes, Digestive and Kidney Diseases (NIDDKD)'s National Hormone and Peptide Program and Dr A F Parlow), dopamine hydrochloride, Ang II and somatostatin (Somatostatin-UCB; Rontag, Buenos Aires, Argentina) were used as stimuli. Times and concentrations were chosen according to our previous experience (Gonzalez Iglesias et al. 2001).

\section{Intracellular $\mathrm{Ca}^{2+}$ measurements}

Fura-2/AM (tetracetoxymethylesther-Fura 2; Molecular Probes, Eugene, OR, USA) was used as a fluorescent indicator. The pellet of anterior pituitary cells was redispersed and incubated in a buffered saline solution (BSS) $\left(140 \mathrm{mM} \mathrm{NaCl}, 3.9 \mathrm{mM} \quad \mathrm{KCl}, 0.7 \mathrm{mM} \quad \mathrm{KH}_{2} \mathrm{PO}_{4}\right.$, $0.5 \mathrm{mM} \quad \mathrm{Na}_{2} \mathrm{HPO}_{4} .12 \mathrm{H}_{2} \mathrm{O}, 1 \mathrm{mM} \quad \mathrm{CaCl}_{2}, \quad 0.5 \mathrm{mM}$ $\mathrm{MgCl}_{2}, 20 \mathrm{mM}$ Hepes $(\mathrm{pH} 7 \cdot 5)$ ) in the presence of Fura-2/AM 1.5 $\mu \mathrm{M}, 10 \mathrm{mM}$ glucose and $0 \cdot 1 \%$ BSA. Cells were incubated for $30 \mathrm{~min}$ at $37^{\circ} \mathrm{C}$ in an atmosphere of $5 \% \mathrm{CO}_{2}$, during which time Fura-2 was trapped intracellularly by esterase cleavage. Cells were then washed twice in BSS without Fura-2/AM, and brought to a density of 1.7 to $2 \times 10^{6}$ cells $/ \mathrm{ml} \mathrm{BSS}$. Fluorescence was measured in a spectrofluorometer (Jasco Corporation, Tokyo, Japan) provided with the accessory CA-261 to measure $\mathrm{Ca}^{2+}$ with continuous stirring, the thermostat adjusted to $37^{\circ} \mathrm{C}$, and an injection chamber. Intracellular $\mathrm{Ca}^{2+}$ levels were registered every second by exposure to alternating 340 and $380 \mathrm{~nm}$ light beams, and the intensity of light emission at $505 \mathrm{~nm}$ was measured. In this way light intensities and their ratio (F340/F380) were followed. Drugs were injected $(5 \mu \mathrm{l})$ into the chamber as a 100 -fold concentrated solution without interruption of recording. The preparation was calibrated by determining maximal fluorescence induced by $0 \cdot 1 \%$ Triton X-100 $\left(\mathrm{F}_{\max }\right)$ and minimal fluorescence $\left(\mathrm{F}_{\min }\right)$ in the presence of $6 \mathrm{mM}$ EGTA (pH adjusted to over $8 \cdot 3$ ). $\left[\mathrm{Ca}^{2+}\right] \mathrm{i}$ was calculated according to Grynkiewicz et al. (1985). Values were corrected for dye leakage as previously described (Grynkiewicz et al. 1985, Gobbe \& Herchuelz 1989), and for autofluorescence with unlabeled cells. Both dye leakage and autofluorescence were minimal.

\section{Intracellular cAMP measurement}

For intracellular cAMP measurements, cells obtained as described above were plated in 24-cell culture plates. After a preincubation of $48 \mathrm{~h}$ with DHEA $\left(1 \times 10^{-5}\right.$ and $1 \times 10^{-6} \mathrm{M}$ ) in BIC-BSA or medium alone (control), 
pituitary cells (300 000 cells/well) were washed and incubated with GHRH $\left(1 \times 10^{-8} \mathrm{M}\right)$, forskolin $\left(1 \times 10^{-7} \mathrm{M}\right)$ or buffer for $30 \mathrm{~min}$ in the presence of 3-isobutyl-1methylxanthine (IBMX, $0 \cdot 1 \mathrm{mM}$ ). After incubation, cells were placed on ice and washed with BIC-BSA, and $0.7 \mathrm{ml}$ cold ethanol added to each well. Cells were scraped, transferred to tubes, sonicated for $15 \mathrm{~s}$, heated for $5 \mathrm{~min}$ at $95{ }^{\circ} \mathrm{C}$ and centrifuged for $5 \mathrm{~min}$ at $9400 \mathrm{~g}$. Supernatants were evaporated, and the dry extracts were suspended in cAMP RIA buffer (NaAc $50 \mathrm{mM}, \mathrm{pH}=6 \cdot 2)$. Intracellular cAMP was measured by RIA as previously described (Del Punta et al. 1996), using the antibody provided by the NIDDKD. Assay sensitivity was $3.3 \mathrm{pg}(10 \mathrm{fmol}) / \mathrm{tube}$. Intra- and interassay coefficients of variation were $8 \cdot 1 \%$ and $10 \cdot 5 \%$ respectively. Experiments were repeated four times. Results are expressed as percentage increase over basal levels (100\%).

\section{Radioimmunoassays}

Prolactin and GH were assayed by RIA with kits provided by the NIDDKD. Results were expressed in terms of prolactin PRL RP3 and GH RP2. Intra- and inter-assay coefficients of variation were $7 \cdot 2$ and $12.8 \%$ respectively for prolactin, and $8 \cdot 3$ and $13 \cdot 1 \%$ for $\mathrm{GH}$.

\section{Statistical analyses}

Results are expressed as means \pm S.E. Effect of different concentrations of DHEA, ADIOL or OH-DHEA on GH or prolactin release, and effects of DHEA on dopamine, somatostatin, Ang II or GHRH action (for prolactin or GH secretion) were analyzed by one-way ANOVA. If F was significant, individual means were compared by Tukey's honest significant difference or Fisher's protected least significant difference tests. The effect of DHEA pretreament on cAMP generation induced by forskolin or GHRH was analyzed by two-way ANOVA. For cell cultures, five rats were used in each experiment, and quadruplicate wells were used for each stimulus. Experiments were repeated four times. In calcium experiments, anterior pituitaries from five rats were pooled for each experiment, and experiments were repeated 6-7 times. Areas under the curve of the plateau response (9-11 min) and peak $\left[\mathrm{Ca}^{2+}\right]_{i}$ responses were compared by paired $t$-tests. $P<0 \cdot 05$ was considered significant.

\section{Results}

Effect of DHEA and its metabolites on prolactin and GH release from anterior pituitary cells in vitro

Pituitary cells were treated for $48 \mathrm{~h}$ with DHEA $\left(1 \times 10^{-5}\right.$, $10^{-6}$ and $\left.10^{-7} \mathrm{M}\right)$, OH-DHEA $\left(1 \times 10^{-7} \mathrm{M}\right)$ or ADIOL $\left(1 \times 10^{-7} \mathrm{M}\right)$. OH-DHEA decreased basal prolactin re-
(A)

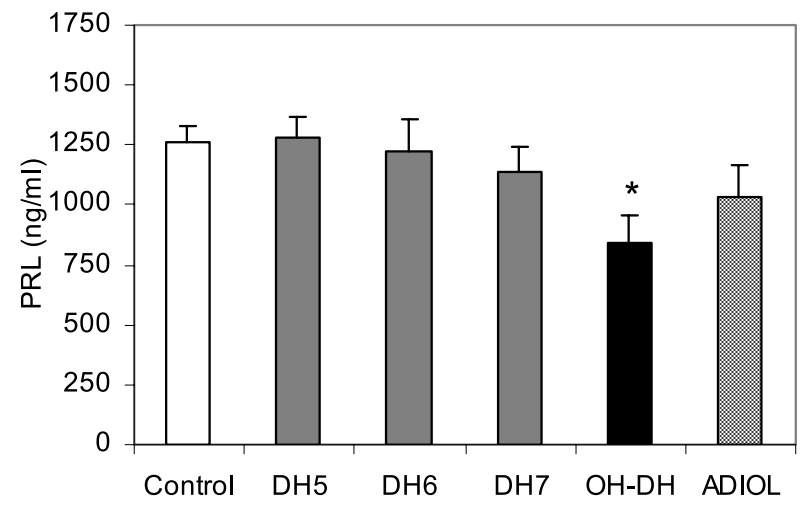

(B)

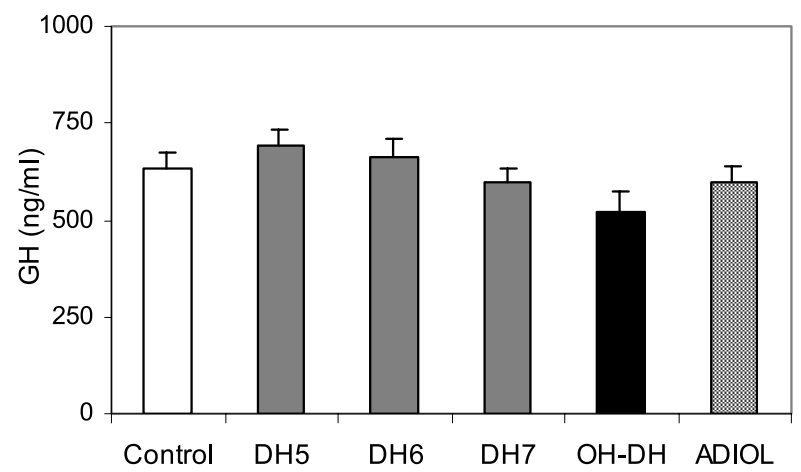

Figure 1 Effect of DHEA and its metabolites on prolactin (PRL) (A) and $\mathrm{GH}$ secretion (B) in dispersed pituitary cells from female rats in diestrus. For this and following figures, DH7: $1 \times 10^{-7} \mathrm{M}$ DHEA, DH6: $1 \times 10^{-6} \mathrm{M}$ DHEA, DH5: $1 \times 10^{-5} \mathrm{M}$ DHEA, OH-DH: $1 \times 10^{-7} \mathrm{M}$ OH-DHEA, ADIOL: $1 \times 10^{-7} \mathrm{M}$ androstenediol. Results are expressed in $\mathrm{ng} / \mathrm{ml}$. * $P<0.05 \mathrm{vs}$ control. $n=7$.

lease $(P=0 \cdot 045)$ (Fig. 1), and there was no significant effect for the rest of the steroids at the concentrations tested on basal prolactin or $\mathrm{GH}$ release.

\section{Effect of DHEA and its metabolites on Ang II-induced} prolactin increase in anterior pituitary cells in vitro

At a concentration of $1 \times 10^{-8} \mathrm{M}$, Ang II did not induce a significant increase in prolactin released to the medium. But DHEA $\left(1 \times 10^{-5} \mathrm{M}\right)$ pretreatment for $48 \mathrm{~h}$ significantly increased the effect of Ang II on prolactin secretion (DHEA $1 \times 10^{-5} \mathrm{M}+$ Ang II and DHEA $1 \times 10^{-6} \mathrm{M}+$ Ang II vs Ang II: $P=0 \cdot 018$ and $P=0 \cdot 066$ ) (Fig. 2A). DHEA alone did not modify prolactin secretion (in $\mathrm{ng} / \mathrm{ml} \pm$ S.E.: $1229 \pm 63,1248 \pm 115,1011 \pm 63$ and $1266 \pm 64$ for $1 \times 10^{-5}, 10^{-6}$ and $10^{-7} \mathrm{M}$ DHEA and control, respectively). In anterior pituitary buffer-treated cells, $1 \times 10^{-8} \mathrm{M}$ Ang II induced a biphasic response of $\left[\mathrm{Ca}^{2+}\right]_{\mathrm{i}}$ (Fig. 2B). It consisted of a 2-6-s delay, followed 


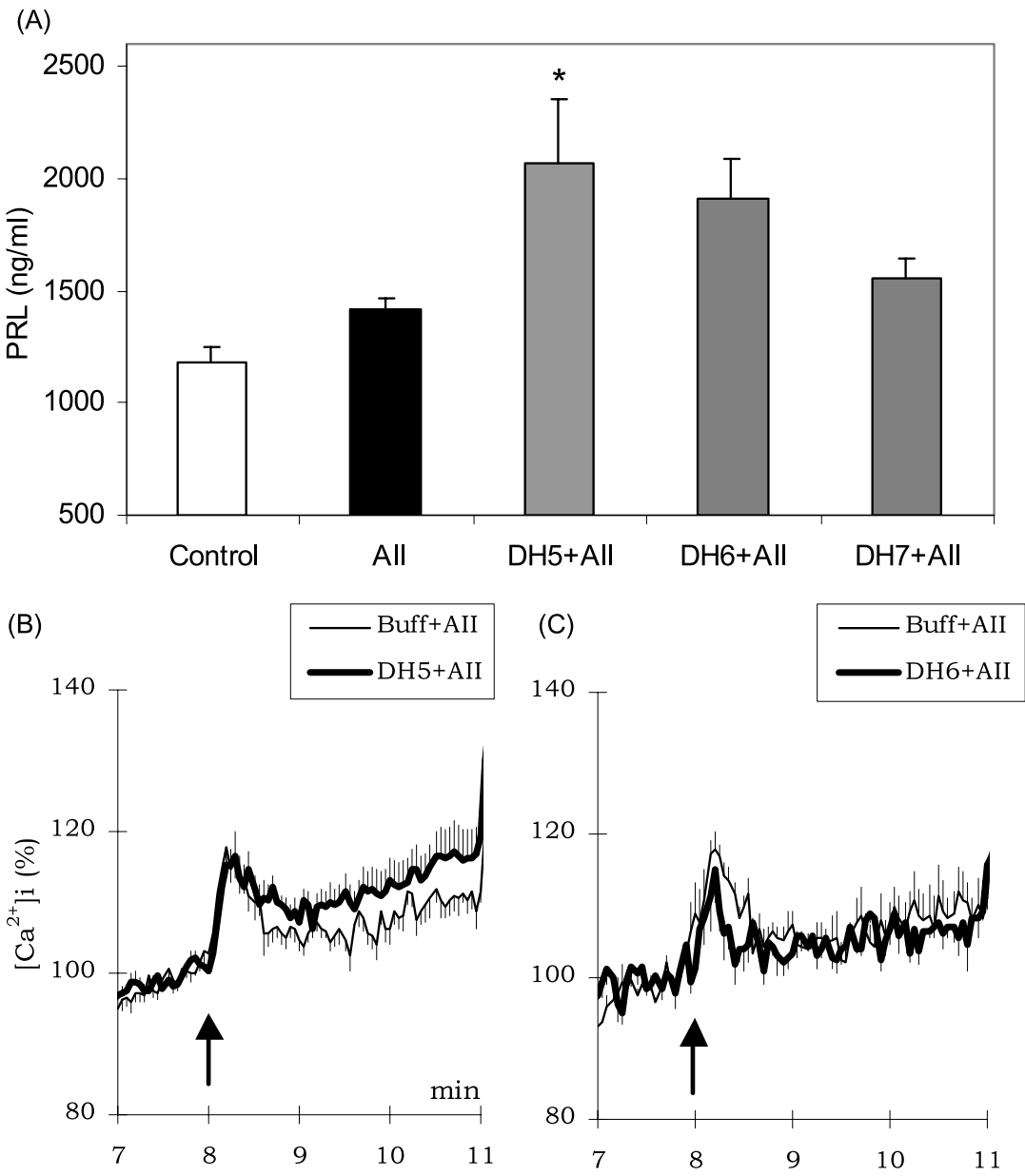

Figure 2 (A) Effect of DHEA on angiotensin II (All, $1 \times 10^{-8} \mathrm{M}$ )-induced prolactin (PRL) release. ${ }^{*} P<0.05$ vs control. $n=6$. (B) $\left[\mathrm{Ca}^{2+}\right]_{i}(\%)$ in cells pretreated with buffer (thin line), $1 \times 10^{-5} \mathrm{M}$ DHEA or (C) $1 \times 10^{-6} \mathrm{M}$ DHEA (thick lines) for $8 \mathrm{~min}$ and then challenged with $1 \times 10^{-8} \mathrm{M}$ All (arrow). $n=7$. Basal $\left[\mathrm{Ca}^{2+}\right]_{\mathrm{i}}$ was considered as the average of $\left[\mathrm{Ca}^{2+}\right]_{\mathrm{i}}$ $20 \mathrm{~s}$ before the All stimulus.

after $14 \pm 2$ s by a peak increase of $20 \%$ (rise from $184 \pm 14$ to a peak of $219 \pm 15 \mathrm{nM}$ ), and a subsequent decay to levels slightly higher than resting levels at $45 \pm 3 \mathrm{~s}$ (plateau phase). DHEA pretreatment at the concentrations of $1 \times 10^{-5}$ and $1 \times 10^{-6} \mathrm{M}$ did not modify the spike phase $\left[\mathrm{Ca}^{2+}\right]_{\mathrm{i}}$ increment induced by $1 \times 10^{-8} \mathrm{M}$ Ang II (Fig. 2B and C) $(P=0.59$ and 0.42 respectively). The plateau phase of $\left[\mathrm{Ca}^{2+}\right]_{\mathrm{i}}$ in response to $1 \times 10^{-8} \mathrm{M}$ Ang II (measured as the area under the curve from 9 to $11 \mathrm{~min}$ ) was not significantly higher in $1 \times 10^{-5}$ or $1 \times 10^{-6} \mathrm{M}$ DHEA-pretreated cells $(P=0.42$ and 0.85 respectively).

Effect of DHEA and its metabolites on dopamine-induced prolactin inhibition in anterior pituitary cells in vitro

Incubation with dopamine $\left(1 \times 10^{-6} \mathrm{M}\right)$ for $3 \mathrm{~h}$ significantly inhibited prolactin release from anterior pituitary cells, but if cells were pretreated for $48 \mathrm{~h}$ with DHEA $\left(1 \times 10^{-5}\right)$, the effect was reduced (DHEA $10^{-5} \mathrm{M}$ plus dopamine vs dopamine $=504 \pm 89$ and $157 \pm 42 \mathrm{ng} / \mathrm{ml}$; $P=0 \cdot 012$ ) (Fig. 3). No significant effect on prolactin inhibition evoked by dopamine was evidenced for ADIOL or OH-DHEA. On the other hand, DHEA by itself $\left(1 \times 10^{-5}, 10^{-6}\right.$ and $\left.10^{-7} \mathrm{M}\right)$ did not modify basal prolactin secretion (see Fig. 1, control data).

Effect of DHEA and its metabolites on GHRH-induced GH release in anterior pituitary cells in vitro

GHRH $\left(1 \times 10^{-8} \mathrm{M}\right)$ increased GH release in vitro (control: $654 \pm 48$, GHRH: $1452 \pm 94 \mathrm{ng} / \mathrm{ml} ; P=0.00013$ ), and DHEA pretreatment for $48 \mathrm{~h}$ augmented the effect of GHRH (DHEA $10^{-5} \mathrm{M}$ plus GHRH and DHEA $10^{-6} \mathrm{M}$ plus GHRH vs GHRH; $P=0.00020$ and 0.000 63 respectively) (Fig. 4). OH DHEA and ADIOL 


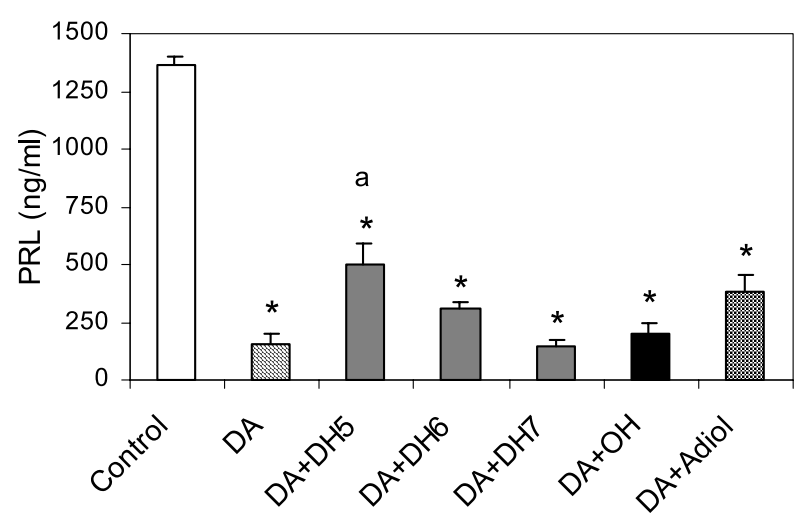

Figure 3 Effect of DHEA and its metabolites on dopamine (DA, $1 \times 10^{-6} \mathrm{M}$ )-induced inhibition on prolactin (PRL) secretion. ${ }^{*} P<0.05$ vs control. a: $P<0.05$ vs DA. $n=4\left(\mathrm{OH}: 1 \times 10^{-7} \mathrm{M}\right.$ OH-DHEA).

had no effect on $\mathrm{GH}$ release induced by GHRH. On the other hand, DHEA by itself $\left(1 \times 10^{-5}, 10^{-6}\right.$ and $10^{-7} \mathrm{M}$ ) did not modify basal GH secretion (see Fig. 1, control data).

Effect of DHEA on GHRH-induced increase in $\left[\mathrm{Ca}^{2+}\right] \mathrm{i}$ in freshly dispersed anterior pituitary cells

When GHRH $\left(1 \times 10^{-8} \mathrm{M}\right)$ was applied to pituitary cells, there was an increment in $\left[\mathrm{Ca}^{2+}\right]_{i}$, and levels remained elevated for at least $3 \mathrm{~min}$ (Fig. 5). If cells were pretreated for $7 \mathrm{~min}$ with $1 \times 10^{-5} \mathrm{M}$ DHEA, this increase was

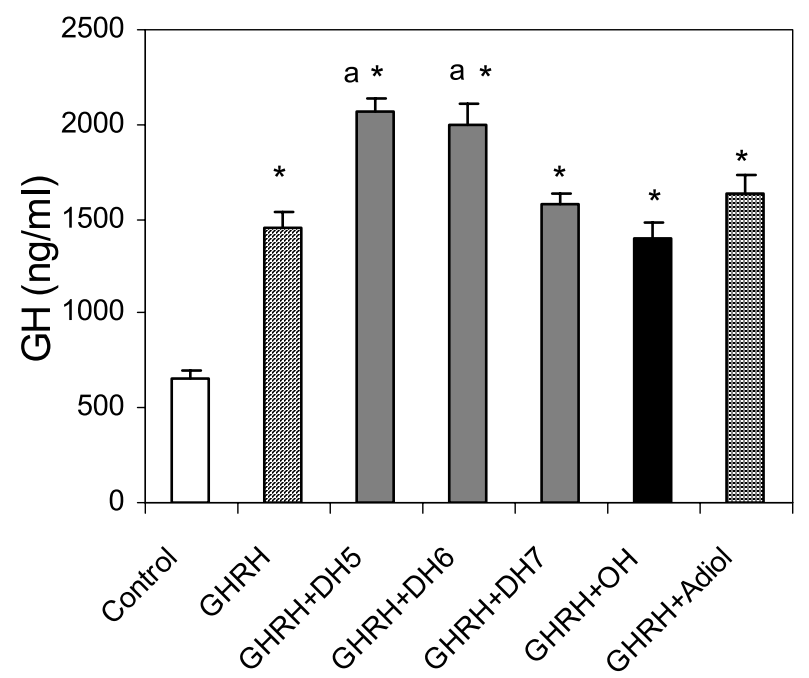

Figure 4 Effect of DHEA and its metabolites on GHRH $\left(1 \times 10^{-8} \mathrm{M}\right)$-induced $\mathrm{GH}$ release. ${ }^{*} P<0 \cdot 05$ vs control. a: $P<0.05$ vs GHRH. $n=7\left(\mathrm{OH}: 1 \times 10^{-7} \mathrm{M} \mathrm{OH}-\mathrm{DHEA}\right)$.

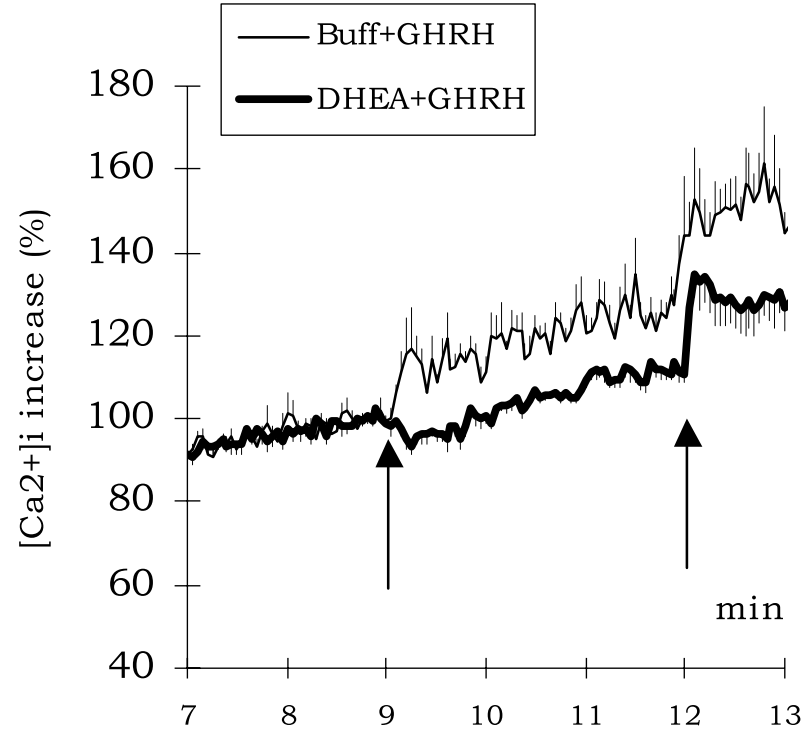

Figure $5\left[\mathrm{Ca}^{2+}\right]_{\mathrm{i}}$ in cells pretreated with $1 \times 10^{-5} \mathrm{M}$ DHEA (thick line) or buffer (thin line) for $8 \mathrm{~min}$ and then challenged with $1 \times 10^{-8} \mathrm{M} \mathrm{GHRH}$ (first arrow). Second arrow corresponds to $25 \mathrm{mM} \mathrm{KCl}$ at $12 \mathrm{~min} . n=6$. Results are expressed as percent increase of $\left[\mathrm{Ca}^{2+}\right]_{\mathrm{i}}$ over basal levels (basal levels were considered as the average of $\left[\mathrm{Ca}^{2+}\right]_{\mathrm{i}} 20 \mathrm{~s}$ before the GHRH stimulus).

blocked $(P=0 \cdot 0013)$. The effect of $25 \mathrm{mM} \mathrm{K}^{+}$-induced increase in $\left[\mathrm{Ca}^{2+}\right]_{\mathrm{i}}$ was not modified by the DHEA pretreatment.

Effect of DHEA on GHRH-induced intracellular cAMP production in anterior pituitary cells in vitro

DHEA pretreatment for $48 \mathrm{~h}$ augmented the effect of GHRH $\left(1 \times 10^{-8} \mathrm{M}\right)$ on cAMP production $(P$ interaction $=0 \cdot 0015-$ DHEA $10^{-5} \mathrm{M}$ plus $\mathrm{GHRH}$ and DHEA $10^{-6} \mathrm{M}$ plus GHRH vs GHRH; $P=0.048$ and 0.0031 respectively) (Fig. 6A). DHEA had no effect on basal cAMP levels. On the other hand, DHEA pretreatment did not modify forskolin-induced cAMP generation $(P$ interaction $=0 \cdot 19$, effect of forskolin; $P=0 \cdot 000$ 21) (Fig. $6 \mathrm{~B})$.

Effect of DHEA and its metabolites on somatostatin-induced $G H$ and prolactin inhibition in anterior pituitary cells in vitro

DHEA pretreatment at the concentrations of $1 \times 10^{-5}$ and $1 \times 10^{-6} \mathrm{M}$ reduced the inhibitory effect of somatostatin $\left(1 \times 10^{-8} \mathrm{M}\right)$ on $\mathrm{GH}$ release (DHEA $10^{-5} \mathrm{M}$ plus somatostatin and DHEA $10^{-6} \mathrm{M}$ plus somatostatin vs somatostatin; $P=0.037$ and 0.037 respectively) (Fig. 7A). On the other hand, the adrenal steroid had no effect on somatostatin inhibition of prolactin secretion (Fig. 7B).

\section{Discussion}

DHEA and DHEA-sulphate (DHEA-S), synthesized by the adrenal gland, are the most abundant steroids 
(A)

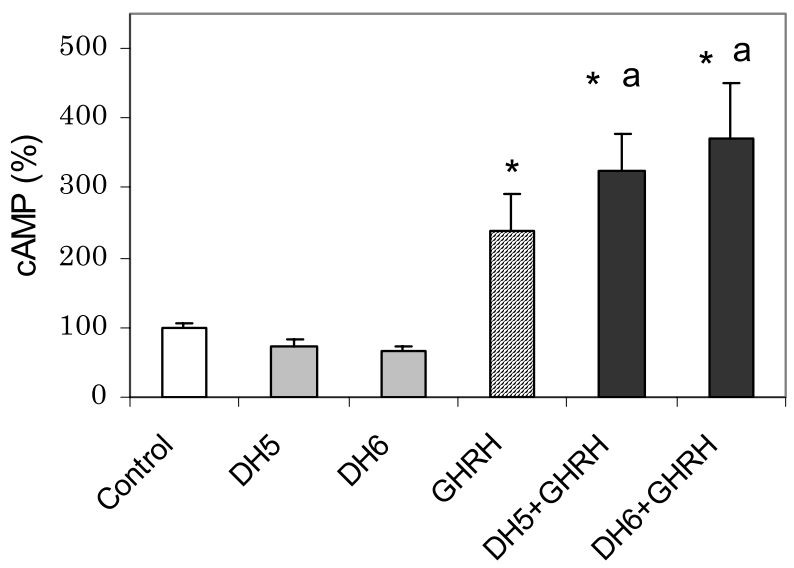

(B)

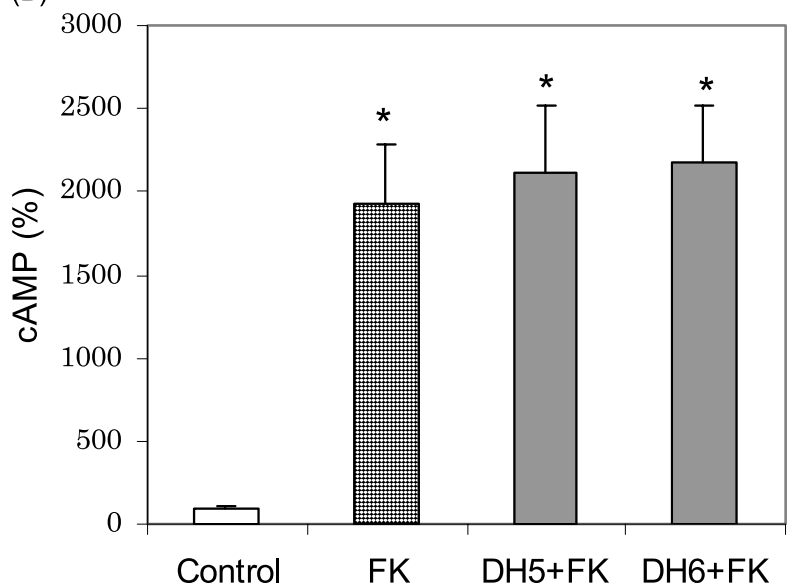

Figure 6 (A) Effect of DHEA (DH6: $1 \times 10^{-6} \mathrm{M}$ DHEA, DH5: $1 \times 10^{-5} \mathrm{M}$ DHEA) on GHRH $\left(1 \times 10^{-8} \mathrm{M}\right)$-induced intracellular CAMP production expressed in percentage $(100 \%$ corresponds to buffer-treated cells (Control). ${ }^{\star} P<0 \cdot 05$ vs control. a: $P<0.05$ vs GHRH. $n=7$. (B) Effect of DHEA on forskolin (FK, $1 \times 10^{-7}$ $M$ )-induced cAMP generation.

circulating in the human blood. In rats, plasma DHEA concentrations are lower, but this animal model has been used to study the effects of DHEA treatment on various disorders (for reviews, see Svec \& Porter 1998; Hinson \& Raven 1999). Recently, there has been a strong resurgence of interest in DHEA because of its suggested antitumoral and antiaging effects, even though its biologic action is still controversial and not clearly defined. In particular, we were interested in evaluating the effect of DHEA at the pituitary level.

DHEA exerts its action in peripheral target tissues either indirectly, after its conversion to androgens, estrogens or both, or directly as a neurosteroid, via interaction with neurotransmitter receptors in the brain. Therefore, it is conceivable that DHEA may modify pituitary function, as neurotransmitters can modify neurohormone or hormone
(A)

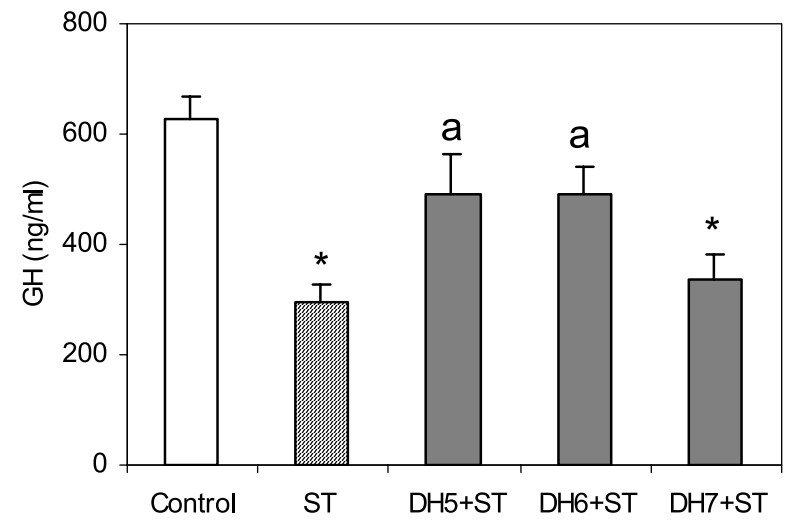

(B)

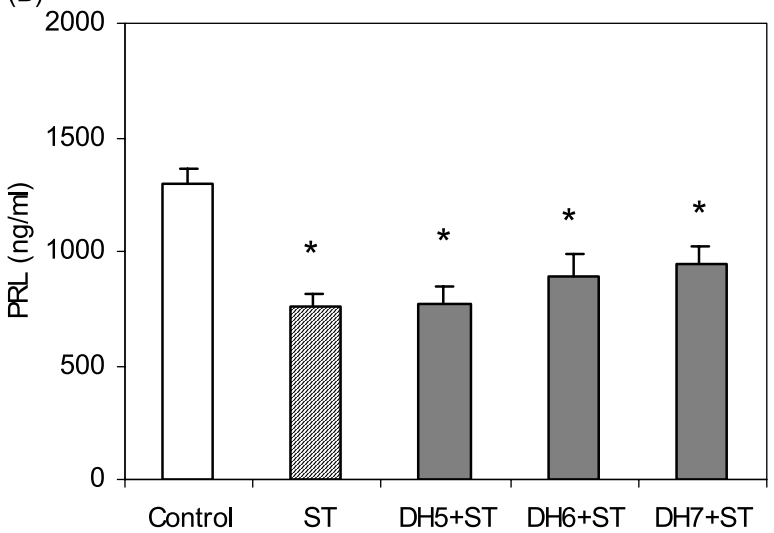

Figure 7 Effect of DHEA on somatostatin (ST, $\left.1 \times 10^{-8}\right)$-induced inhibition of (A) GH and (B) prolactin (PRL) release. ${ }^{*} P<0.05$ vs control. a: $P<0.05$ vs ST. $n=7$.

release, acting at the hypothalamus or the pituitary, and both structures are target tissues for steroids. From a physiologic/developmental point of view, plasma DHEA levels in both genders are very low in the infantile period, increase rapidly at puberty, and thereafter decrease linearly and age-dependently, low levels being found in senescence.

In a previous work we showed that in pituitary hyperplasia induced by estrogen in female rats, DHEA had several endocrine and metabolic effects, which depended mainly on the endocrine environment (Suárez et al. 2002). We found that DHEA enhanced serum prolactin in rats in diestrus, though it partially reversed estrogen-induced hyperprolactinemia. Consequently, DES-induced pituitary enlargement was reduced by cotreatment with DHEA, but DHEA by itself slightly increased pituitary weight. The fact that in the presence of high estrogen levels the action of DHEA could be reversed may indicate that the endocrine environment conditions the effect of the adrenal steroid. In accordance, the present results showed that the effect of DHEA in vitro was different 
depending on the presence or absence of an inhibitory tone (dopamine). In vitro, DHEA partially reduced the inhibition of prolactin secretion induced by dopamine. And in the absence of dopamine, it did not modify prolactin release in vitro, even though one of its metabolites, OH-DHEA, inhibited prolactin secretion.

Numerous observations indicate that Ang II can contribute to the physiologic regulation of prolactin secretion (Freeman et al. 2000), and that it releases prolactin both in vivo and in vitro (Diaz-Torga et al. 1994, 1998). Angiotensin II receptors, which mediate prolactin secretion (AT1), belong to the family of G protein-coupled receptors. In the rat pituitary, most AT1 receptors are located on lactotropes (Moreau et al. 1997), and their activation is coupled to a $G_{\mathrm{q} / 11}$ protein which increases phospholipase C- $\beta$ activity, resulting in inositol 1,4,5triphosphate and diacylglycerol (DAG) formation, followed by a biphasic increase in $\left[\mathrm{Ca}^{2+}\right]_{\mathrm{i}}$ (Suárez et al. 2003). In the present experiments the effect of Ang II on prolactin secretion was enhanced by previous treatment with DHEA, even though $\mathrm{Ca}^{2+}{ }_{\mathrm{i}}$ mobilization was not modified, suggesting that a different intracellular messenger was mediating its action. It has been shown that pituitary sensitivity to Ang II stimulation is modulated by steroid hormones and is related to the gender of the animal (Diaz-Torga et al. 1998, Lachowicz \& Rebas 2002).

In experiments in rats in vivo we had observed that DHEA increased serum GH levels (Suárez et al. 2002). Furthermore, it has also been reported that serum DHEA levels correlate positively with GH and IGF-I levels in nonobese women with functional hyperandrogenism (Legan et al. 2002), in pubertal development, and in aging (Shealy 1995, Kroboth et al. 1999). DHEA replacement in old healthy people as well as in patients with primary adrenal insufficiency produced an increase in serum IGF-I (Arlt et al. 1999). It was therefore of interest to study the interaction of DHEA with GHRH- and somatostatininduced secretion of $\mathrm{GH}$ at the pituitary level.

Our results proved that DHEA did not modify basal GH secretion, but did enhance the GH-releasing effect of GHRH. It has been shown that GHRH action on GH secretion is mediated by a host of intracellular, secondmessenger systems including, among others, cAMP production and $\mathrm{Ca}^{2+}{ }_{i}$ mobilization (Müller et al. 1999). GHRH stimulation of cAMP production is related to the coupling of the GHRH receptor to a $G$ protein $\left(G_{s}\right)$, and GHRH-induced increase in $\left[\mathrm{Ca}^{2+}\right]_{\mathrm{i}}$ to stimulation of $\mathrm{Ca}^{2+}$ influx through L-type, voltage-operated calcium channels (Lussier et al. 1991). We observed that DHEA enhanced cAMP production evoked by GHRH, and not by forskolin, a stimulatory agent of adenylate cyclase, indicating that this was a GHRH-receptor-specific effect. On the other hand, DHEA prevented the GHRH-induced increase in $\left[\mathrm{Ca}^{2+}\right]_{\mathrm{i}}$. These results suggest that the facilitatory action of DHEA on GHRH-induced GH release is mediated by cAMP formation, and not by $\mathrm{Ca}^{2+}$ influx. Nevertheless, other second messengers may also be involved. On the other hand, DHEA pretreatment reduced the inhibitory action of somatostatin on $\mathrm{GH}$, and not on prolactin, secretion. These results could be related to the DHEAinduced reversal of the inhibitory effect of ether stress on GH secretion, which we have previously described (Suárez et al. 2002). From our results, it can be inferred that DHEA may release $\mathrm{GH}$ in vivo by reducing somatotrope responsiveness to somatostatin, as well as by enhancing somatotrope sensitivity to GHRH.

We conclude that DHEA in vitro, directly or indirectly through conversion into metabolites, is able to modulate the hormonal response of the pituitary to hypothalamic regulators. It can enhance pituitary prolactin release by a partial reversal of dopamine inhibition, and by a facilitation of the Ang II secretory action. On the other hand, DHEA can also induce GH secretion by reducing the inhibitory action of somatostatin and by stimulating the GHRH releasing effect. In vitro effects described herein correlate well with those observed in vivo. DHEA administration in excess of normal baseline levels might carry the risk of promoting sex-hormone-dependent neoplasia (Maggiolini et al. 1999). In rodents, for example, long-term administration of DHEA produced uterine enlargement and precocious ovulation followed by ovulatory failure with low circulating luteinizing hormone levels (Knudsen et al. 1975). In addition to its potential hormonal side effects, it has been reported that DHEA can produce hepatomegaly (Rao et al. 1992). The results described herein could help to explain some of the hormonal side effects observed in prolonged DHEA in vivo treatments and should be taken into account when considering its use in human clinical trials.

\section{Acknowledgements}

This work was supported by grants from CONICET and Agencia Nacional de Promoción Científica y Técnica, Buenos Aires, Argentina (DBV) and Beca Ramón Carrillo Oñativia, Ministerio de Salud (CS). We thank the NIDDKD's National Hormone and Pituitary Program and Dr A F Parlow for cAMP antibody, and GH and prolactin RIA kits. The authors declare that there is no conflict of interest that would prejudice the impartiality of this scientific work.

\section{References}

Allolio B \& Arlt W 2002 DHEA treatment: myth or reality? Trends in Endocrinology and Metabolism 13 288-294.

Arlt W, Callies F, van Vlijmen JC, Koehler I, Reincke M, Bidlingmaier M, Huebler D, Oettel M, Ernst M, Schulte HM \& Allolio B 1999 Dehydroepiandrosterone replacement in women with adrenal insufficiency. New England Journal of Medicine 341 1013-1020. 
Del Punta K, Charreau E \& Pignataro OP 1996 Nitric oxide inhibits Leydig cell steroidogenesis. Endocrinology 137 5337-5343.

Diaz-Torga GS, Becu-Villalobos D \& Libertun C 1994 Ontogeny of angiotensin-induced prolactin release in vivo and in vitro in female and male rats. Neuroendocrinology 59 57-62.

Diaz-Torga GS, Gonzalez Iglesias A, Achaval-Zaia R, Libertun C \& Becu-Villalobos D 1998 Angiotensin II induced calcium mobilization and prolactin release in normal and hyperplastic pituitary cells. American Journal of Physiology - Endocrinology and Metabolism 274 E534-E540.

Ebeling P \& Koivisto VA 1994 Physiological importance of dehydroepiandrosterone. Lancet 343 1479-1481.

Freeman ME, Kanyicska B, Lerant A \& Nagy G 2000 Prolactin: structure, function, and regulation of secretion. Physiological Reviews 80 1523-1631.

Gobbe P \& Herchuelz A 1989 Effects of verapamil and nifedipine on gliclazide-induced increase in cytosolic free $\mathrm{Ca}^{2+}$ in pancreatic islet cells. Journal of Endocrinological Investigation 12 469-474.

Gonzalez Iglesias A, Diaz-Torga G, Piroli G, Achaval-Zaia R, De Nicola AF, Libertun C \& Becu-Villalobos D 2000 Bromocriptine restores angiotensin II response in pituitary hyperplasia. Molecular and Cellular Endocrinology 165 67-74.

Gonzalez Iglesias A, Suárez C, Feierstein C, Diaz-Torga G \& Becu-Villalobos D 2001 Desensitization of angiotensin II: effect on $\left[\mathrm{Ca}^{2+}\right]_{\mathrm{i}}$, inositol triphosphate, and prolactin in pituitary cells. American Journal of Physiolog $\gamma-$ Endocrinology and Metabolism 280 E462-E470.

Grynkiewicz G, Poenie M \& Tsien RY 1985 A new generation of $\mathrm{Ca}^{2+}$ indicators with greatly improved fluorescence properties. Journal of Biological Chemistry 260 3440-3450.

Hinson JP \& Raven PW 1999 DHEA deficiency syndrome: a new term for old age? Journal of Endocrinology $1631-5$.

Knudsen JF, Costoff A \& Mahesh VB 1975 Dehydroepiandrosterone induced polycystic ovaries and acyclicity in the rat. Fertility and Sterility 26 807-817.

Kroboth PD, Salek FS, Pittenger AL, Fabian TJ \& Frye RF 1999 DHEA and DHEA-S: a review. Journal of Clinical Pharmacology 39 327-348.

Lachowicz A \& Rebas E 2002 Gender differences in steroid modulation of angiotensin II-induced protein kinase C activity in anterior pituitary of the rat. Biochemical and Biophysical Research Communications 294 95-100.

Legan M, Kocijancic A, Prezelj J, Osredkar J \& Fisker S 2002 GH-IGF-I axis in non-obese women with functional hyperandrogenism. Journal of Endocrinological Investigation $\mathbf{2 5}$ 691-695.
Lussier BT, French MB, Moor BC \& Kraicer J 1991 Free intracellular $\mathrm{Ca}^{2+}$ concentration $\left(\left[\mathrm{Ca}^{2+}\right]\right)$ and growth hormone release from purified rat somatotrophs. I. GH-releasing factor-induced $\mathrm{Ca}^{2+}$ influx raises $\left[\mathrm{Ca}^{2+}\right]$. Endocrinology 128 570-582.

Maggiolini M, Donze O, Jeannin E, Ando S \& Picard D 1999 Adrenal androgens stimulate the proliferation of breast cancer cells as direct activators of estrogen receptor alpha. Cancer Research $\mathbf{5 9}$ 4864-4869.

Moreau C, Rasolonjanahary R, Zamora AJ, Enjalbert A, Kordon C \& Llorens-Cortes C 1997 Expression of angiotensin II receptor subtypes $\mathrm{AT}(1 \mathrm{~A})$ and $\mathrm{AT}(1 \mathrm{~B})$ in enriched fractions of dispersed rat pituitary cells. Neuroendocrinology 66 416-425.

Müller E, Locatelli V \& Cocchi D 1999 Neuroendocrine control of growth hormone secretion. Physiological Reviews 79 511-607.

Poortman J, Prenen JAC, Schwarz F \& Thijssen JHH 1975 Interaction of delta-5 - androstene- 3 beta, 17 beta-diol with estradiol and dihydrotestosterone receptors in human myometrial and mammary cancer tissue. Journal of Clinical Endocrinology and Metabolism $\mathbf{4 0}$ 373-379.

Rao MS, Subbarao V, Yeldandi AV \& Reddy JK 1992 Hepatocarcinogenicity of dehydroepiandrosterone in the rat. Cancer Research 52 2977-2979.

Rose K, Allan A, Gauldie S, Stapleton G, Lorraine D, Dott K, Martin C, Wang L, Hedlund E, Seckl JR, Gustafsson J-A \& Lathe R 2001 Neurosteroid hydroxylase CYP7B. Vivid reporter activity in dentate gyrus of gene-targeted mice and abolition of a widespread pathway of steroid and oxysterol hydroxylation. Journal of Biological Chemistry $27623937-23944$.

Shealy CN 1995 A review of dehydroepiandrosterone (DHEA). Integrative Physiological and Behavioral Science 30 308-313.

Suárez C, García-Tornadú I, Khalil W \& Becu-Villalobos D 2002 Dehydroepiandrosterone treatment attenuates estrogen induced pituitary hyperplasia. Journal of Endocrinology 174 447-454.

Suárez C, Diaz-Torga G, Gonzalez-Iglesias A, Vela J, Mladovan A, Baldi A \& Becu-Villalobos D 2003 Angiotensin II phosphorylation of extracellular signal regulated kinases in rat anterior pituitary cells. American Journal of Physiology - Endocrinology and Metabolism 285 E645-E653.

Svec F \& Porter J 1998 The actions of exogenous dehydroepiandrosterone in experimental animals and humans. Proceedings of the Society of Experimental Biology and Medicine 218 174-191.

Received 7 January 2005

Accepted 18 January 2005 